\title{
GEOGRAPHICAL TENDENCIES OF MAIN PRODUCE IMPORTS OF LATVIA 2000-2015
}

\author{
Antons Berjoza, Juris Paiders \\ University of Latvia \\ antons.berjoza@inbox.lv; jpaiders@inbox.lv
}

\begin{abstract}
Foreign trade as part of the main economic relationship between a country and the global market, its regions and super-players is a significant research object. This paper deals with a particular case, exploring Latvian import in first one and a half decade of the $21^{\text {st }}$ century. Since in Latvian academic society economic issues are largely dominated by economic scientist, this is an attempt by geographer to look at special aspects of mentioned ties and relationships. Research is focused around main producing sectors of economy such as agriculture, fisheries and forestry.

With the aim of establishing clear ties between Latvia and its major import markets, the statistics of foreign trade was analysed using frequency analysis. The research shows that Latvian major import markets, although, similarly with its export markets, are located in the Baltic Sea region and have some differences. Major import markets are usually countries with bigger internal market, than Latvia's. Import does follow the pattern of export markets in its separation into East and West groups with similar characteristics. Major difference, however, is differentiation of markets, where majority of high quality goods are being imported from a wider variety of markets, in contrast to export, where consolidation was a major pattern. This shows a rather close competition on world markets for potential clients, and a way for further economic change in Latvian industrial structure and operations.
\end{abstract}

Key words: foreign trade, frequency analysis, agriculture, forestry, fisheries.

\section{Introduction}

This paper is a continuation of a bigger research, first published in 2015 (Berjoza \& Paiders, 2015), where export markets and flow of goods in similar economic sectors were studied. Foreign trade is an important aspect of international economy and relations. Today economic ties between two countries may be considered a stronger bond than religious, cultural or political ones (Birzins, 2004). Hence, it is imperative to study this phenomenon in its fullest and amass not only empirical data, but also qualitative data to efficiently and precisely analyse causes and consequences of changing dynamics of modern economy.

Foreign trade consists of two distinct flows of goods and services - export and import. Later unlike the first is not generated locally, but is acquired in foreign markets and brought in by entrepreneurs and locals to satisfy the demand. There is no contradiction, as the 'generation' mentioned above refers to production of product or service, not the demand for it. In a broader view, it is possible to speculate that all economic actions are generated locally steaming from the local demand, but that is not always true, and even more often it is not accurate. This research, however, attempts to explore import markets in similar manner as its authors did in their previous work (Berjoza \& Paiders, 2015) - to analyse the spatial development of foreign trade of Latvia in particular, its import markets of major commodity groups using frequency analysis. This is achieved by:

- evaluating the existing extent of research in the field and completing a statistical overview in the period of interest;
- gathering import data of main commodity groups and using frequency analysis to pinpoint the major and continuously stable markets;

- analysing the results of the frequency analysis and interpreting them with additional qualitative data to explain a positive or negative trend, without relying on pure empirical data.

It is also important to note other works in this field dealing with similar problems. For example, foreign trade influence on sectoral development (Chaney, 2014; Novy, 2013; Bērtaite \& Liepa, 2011, Kantar et al., 2011), long term changes in foreign trade of one region, country or its group (Eaton et al., 2011; Berentsen, 2012; Devaeva, 2006), foreign trade as a descriptor of international integrity and a tool for further European/World integration (Fadejeva \& Melihovs, 2009), its role in industrial (Gingrich, 2011; Villoria \& Hertel, 2011) or socio-economic (Herekenrath, 2007) development, finally, foreign trade as international relations and influence tool (Bergeijk, 2009; Haibo, 2004) (for more reference to Berjoza \& Paiders, 2015).

\section{Materials and Methods}

The data used in this research were taken from the Central Statistical Bureau of Latvia. The data from the year 2000 to 2015 were collected for all foreign trade transactions in the selected groups, which represented the major sectors of the Latvian economy such as agriculture, fisheries and forestry. The data from the whole data set were selected based on four digit international goods nomenclature:

02 - Meat and its processed goods;

03 - Fish and its processed goods; 
04 - Milk and its processed goods;

10 - Grains;

11 - Grain processed goods;

16 - Prepared foodstuffs and conserves;

44 - Forestry goods;

The mentioned groups were further processed to fit the preliminary analysis criteria by being sorted by a year, month, and country in one matrix. The preliminary analysis involved the preparation of a binary matrix, by substituting any positive trade instance for 1 and the rest for 0 . Using the formula below, a frequency of import can be calculated:

$$
\begin{aligned}
& \mathrm{P}=\sum(\mathrm{N} 1+\mathrm{N} 2+\mathrm{N} 3+\ldots+\mathrm{Nx}) / \mathrm{X} \\
& \text { Frequency calculation formula }
\end{aligned}
$$

Where $-\mathrm{P}$ is frequency,

$\mathrm{X}-$ is a number of months in the observed period, and $\mathrm{N}-$ is a value for every month in the matrix. Thus, the analysis gives a string of frequencies that describe the import frequency for any import position of goods to a given state. For further analysis, the data were transformed again combining all the data into 5 major groups: 02 - meat products, 03 - fish products, 04 - milk products, 10 - grains and its products and 44 - forestry products. Further some countries were excluded (Yugoslavia and its succession states, Sudan and ex-Dutch colonies in the Caribbean), as they were in the periods of transition, and these might have caused serious misinterpretations and heterogeneities in the matrixes.

The transformed data of 5 columns were used in calculating a function from the relative frequency that would give an opportunity to determine whether the $\mathrm{H}_{0}$ could be dismissed. $\mathrm{H}_{0}$ was formulated as follows: import from any selected country/market at any selected time is random in nature. For that purpose, R. Fisher $\varphi$-function is the best (See Formula 2) (Krastiňš \& Ciemina, 2003).

$$
\varphi=\frac{2 \pi}{180} \arcsin (\sqrt{p})
$$

Fisher $\varphi$ calculation formula, where $\mathrm{p}$ - is frequency

Then, using formula in Figure 3, t-empirical can be calculated, and using formula in Figure $4 \mathrm{t}$-theoretical can also be obtained:

$$
t_{a}=\frac{\left|\varphi_{1}-\varphi_{2}\right|}{\sqrt{\frac{n_{1}+n_{2}}{n_{1} \times n_{2}}}}
$$

$\mathrm{T}_{\mathrm{emp}}$ calculation formula

$$
v=n_{1}+n_{2}-2
$$

$\mathrm{T}_{\text {theo }}$ calculation formula

Formula 4 shows the calculation for the degrees of freedom, where $n_{1}$ is the number of observations in the general set, but $\mathrm{n}_{2}$ the number of observations for one country, $\varphi_{1}$ is Fisher transformation for indicator frequency for the general set, $\varphi_{2}$ is Fisher transformation for indicator frequency in the general for one country: $V$ - Number of the degrees of freedom; $\mathrm{T}$-theoretical is based on the $\mathrm{T}$ - distribution (T-tables) according to degrees of freedom.

As a result, it is possible to obtain $T_{\text {emp }}$ value that can give a relative frequency from which it is possible to speculate a possibility of import occurring in any randomly selected month from the country under observation. Hence, all countries can be divided into 3 groups, after the calculation of t-statistics of significance:

1. Import markets - where the import occurrence probability is statistically high - where $T_{e m p}$ is greater than 2, and the average frequency of the import group is smaller than that of the observed country;

2. Import markets - where the import occurrence probability is statistically low $-\mathrm{T}_{\text {emp }}$ is greater than 2, and the average frequency of the import group is greater than that of the observed countries. This group also includes all the countries with no import records;

3. Import markets - where import has eventual character $-\mathrm{T}_{\mathrm{emp}}$ is less than 2 , and $\mathrm{H}_{0}$ cannot be dismissed.

\section{Results and Discussion}

This paper is a continuation of a previous publication (see Berjoza \& Paiders, 2015), with its focus on import rather than export. Compared to export, which is being locally produced or created from local and imported resources, import is fuelled, first of all, by local consumption and then a need for resources for further production that stimulates export. Thus this part of the study can be viewed as an attempt to connect the flows of goods into a loop that can loosely be described as part of global economic cycle.

Starting of the analysis, in order of succession, first (i.e. meat and its products) group of goods is one of very short preservation time, thus its geography as noted before (Berjoza \& Paiders, 2015) is limited. Significant markets are shown in Figure 1, where it can be seen to be restricted to European countries only. Here it can be largely attributed to the advantages of EU common economic space and the fact that Latvia itself does not produce enough raw meat in any form 


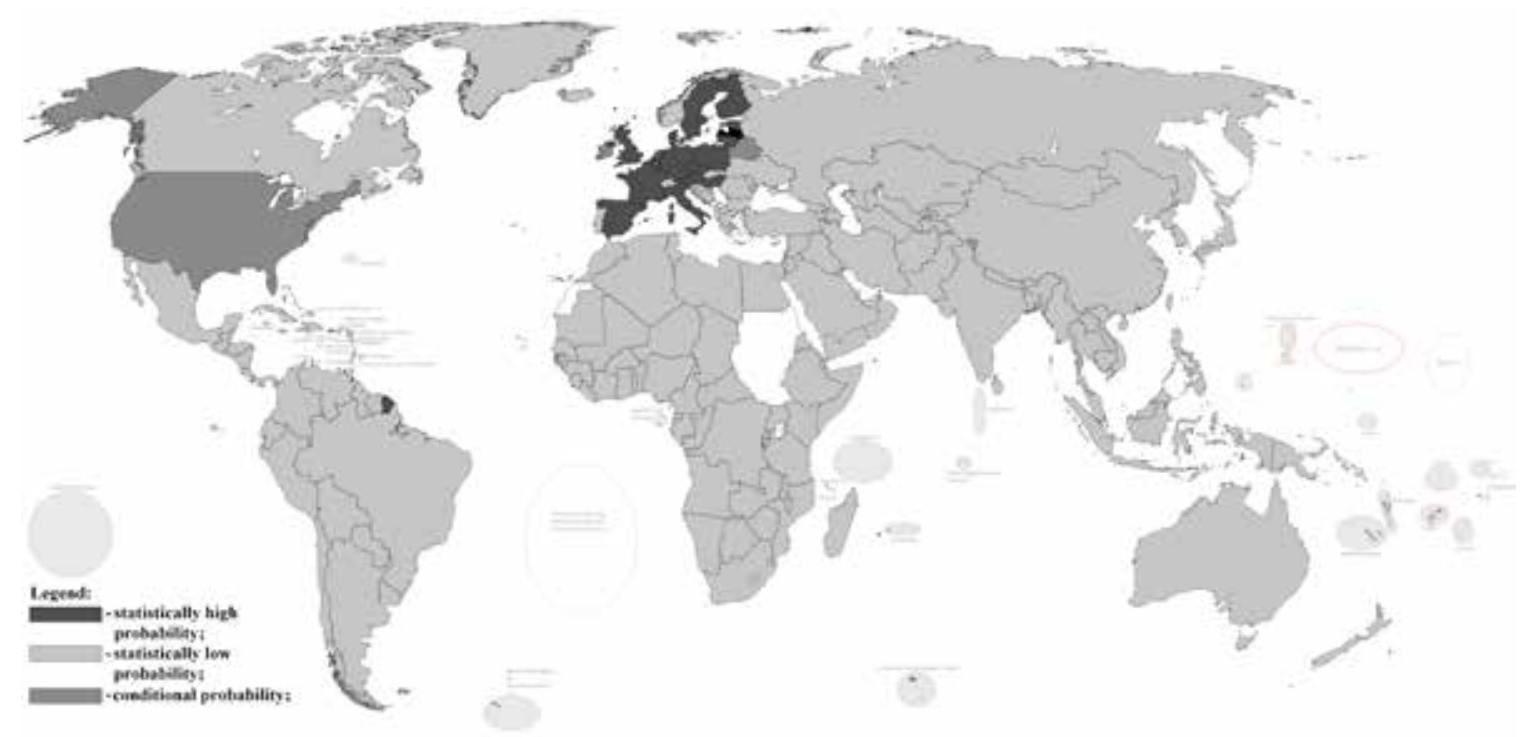

Figure 1. Import markets by probability for meat and its products in the observed period.

to fully supply its internal demand and support more sophisticated production.

Looking into this group in detail, it reveals that main import markets for unprocessed meat are relatively close to Latvia and encompass the Baltic Sea region, similarly to its export markets (Berjoza \& Paiders, 2015). On the other hand, more distant partners such as France, Italy Spain and Benelux nations dominate the processed and well-preserved product import. Fresh, chilled and frozen meat mostly being imported from Poland, Germany, Lithuania, Hungary, Estonia and Denmark. Finland, Sweden, Austria and UK can be considered in the balance zone, where both raw and processed meat products are being imported in balance to each other.

Research also reveal that major trading partners are Poland, Germany, Lithuania and Estonia, while more distant countries such as Spain, Italy, France and UK can be described as premium goods importers, which means constant import of high quality produce in small amounts for relatively high prices. In case of the USA and Belarus, the methodology did not show a constant economic connection that can be both a sign of declining or developing economic relations.

Continuing the analysis of the second (i.e. fish and fish products) group, it can be noted that import markets are similar to export markets, though, there persist differences. The overall geography of import markets is wider than it was for export ones (Berjoza $\&$ Paiders, 2015). There are various new countries involved such as New Zealand, Argentina, Uruguay, Chile, Indonesia and Philippines. Similarly, largest import markets are the ones in the Baltic Sea region - Lithuania, Estonia, Finland, Sweden, Denmark and Germany although now there appear to be some other big importers like Norway, UK, France, Spain and USA. Analysed by product groups, most of fresh or chilled fish are being imported from closer markets, while frozen fish is being delivered from every corner of the world, including destinations like Thailand, Vietnam, China, New Zealand and Argentina. A number of import markets, mostly in Asia and South America, fall into a variable probability group and the best explanation to this is unstable nature of trade relations and distance.

There are significant changes in market pattern in Europe, as most of the east and south European countries lose their significance, compared to previous study of export (Berjoza \& Paiders, 2015). It can be explained with the fact that those countries do not produce demanded goods for Latvian markets, which is being filled with qualitative and relatively cheap products of German, French, British and Italian fish industries. It can be noted particularly well in import values of preserved and canned fish imports, where largest markets are the closest ones to Latvia geographically and are the members of European common market. Eastern and non-EU partners remain, but their significance strongly varies due to external factors (here various major political and economic occurrences).

In Figure 2, it can be observed that milk and dairy import markets are rather diverse, but a sense of eastwest division remains. It is particularly visible due to insignificance of Belarus and Ukraine. In general, major markets for fresh milk and other fresh dairy products are close to Latvia - them being Lithuania, Estonia, Poland, Germany, Denmark and Russia. On the other hand, more distant EU countries like France Benelux, Spain and Italy mostly participate in import of expensive high quality goods such as cheese. The 


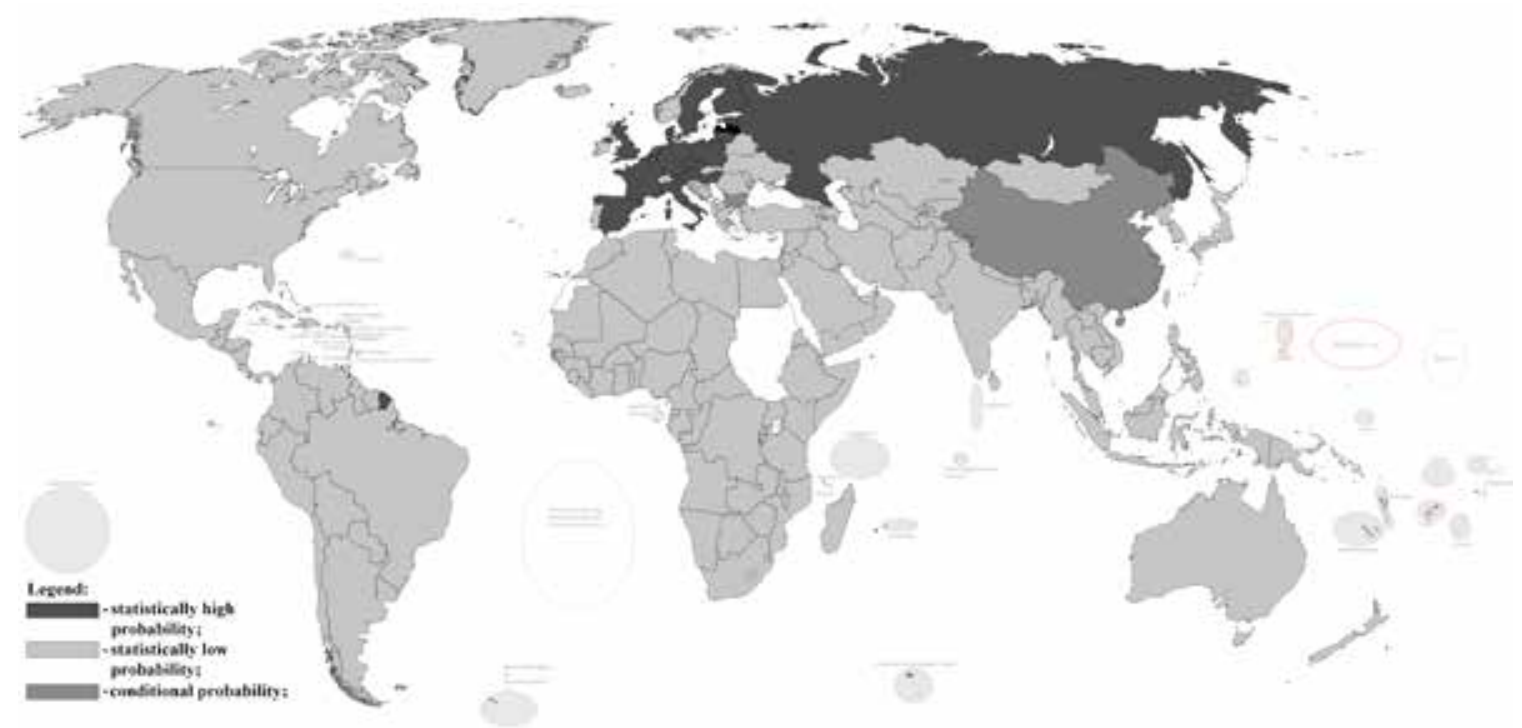

Figure 2. Import markets by import probability for milk and dairy in the observed period.

$3^{\text {rd }}$ group of products can be divided into two distinct sections - that of fresh goods, with short preservation and expiration times, and that of fermented goods, which can be stored considerably longer. Thus, it can be said that immediate neighbours of Latvia are bigger import markets as they can produce and trade both fresh and fermented good of general consumption, while more distant markets may provide luxurious or high quality fermented products.

In Figure 3 a good example of such can be observed. Among 7 biggest importers of cheese and cottage cheese are both close and distant countries. So it can be noted that with time international trade grew and developed greatly increasing amounts of import from Lithuania, Poland and Estonia, while demand for relatively expensive goods from France and Italy remained low. In this Figure, it can also be noted how major political and economic occurrences - around 2004, 2009 and 2014 have influenced the amounts of import.

It is safe to assume, that in 2004 with Latvia's accession to the EU its imports began to grow significantly, but in 2009 suffered a short but still visible damage from recession and financial crisis. Although crisis struck many sectors, imports of cheese and cottage cheese recovered quickly (which also indicates the collapse of local produce); it fell again in 2014 with some recovery next year. Here the

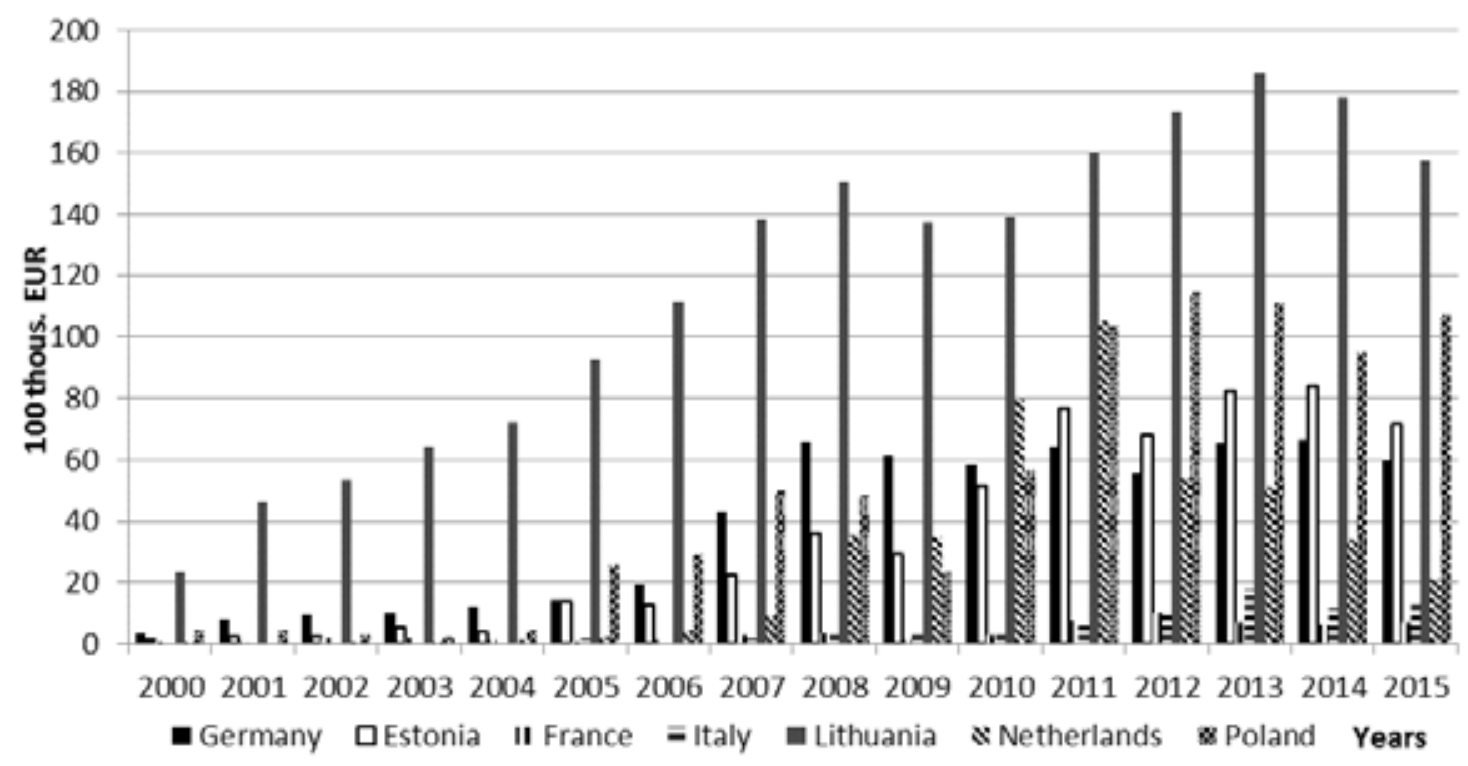

Figure 3. Cheese and cottage cheese import volumes by major import markets in the observed period. 


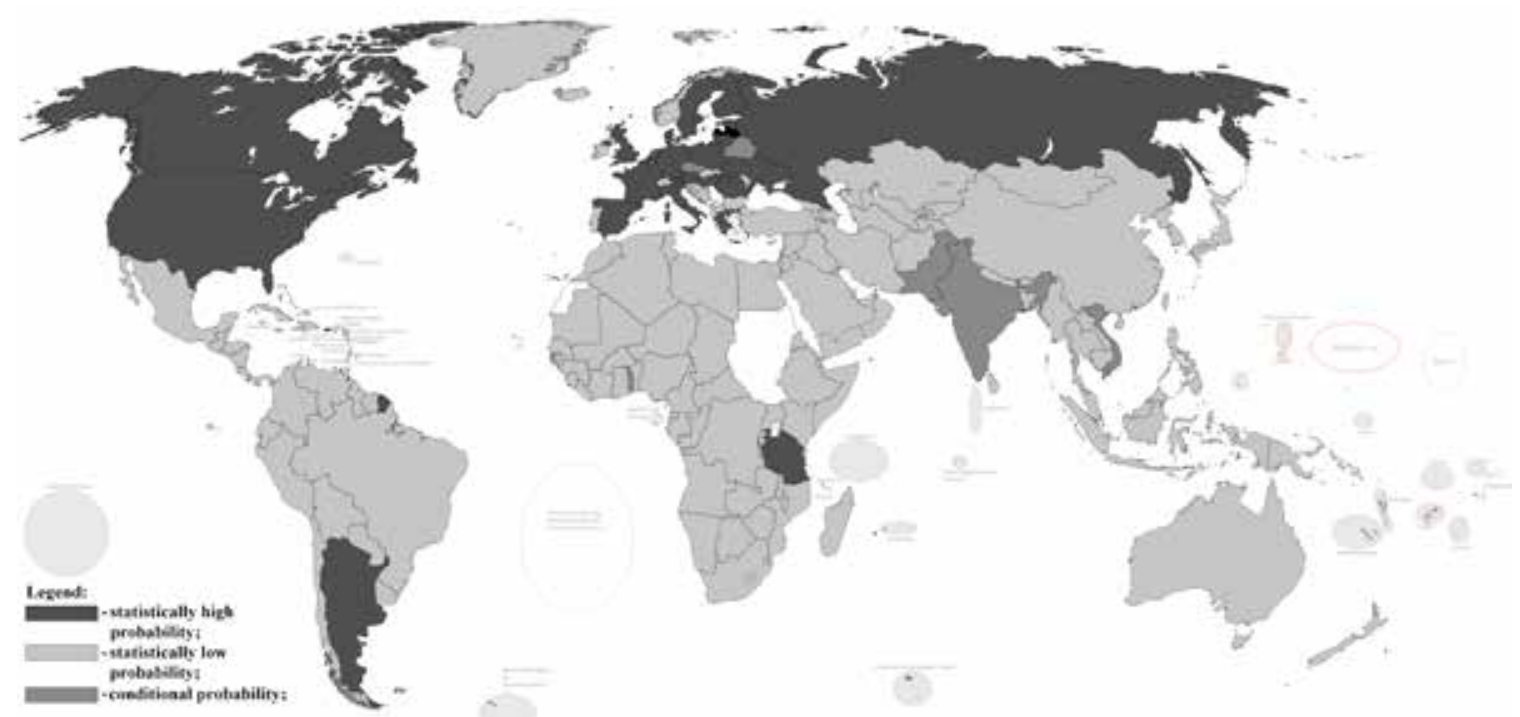

Figure 4. Import markets by import probability for grain and its products in the observed period.

changes might be attributed to oversaturation of local and global markets due to worsening of political and economic situation in the region.

The forth (i.e. grain and it products) group is a relatively complex one, as it has many positions involved and requires a more detailed inspection. Figure 4 shows import markets for all 21 produce positions and indicates most significant partners in Europe, Americas, Asia and even Africa; on the other hand, in Figure 5 particular positions import markets can also be observed. Comparing them reveals, that wheat and wheat-rye mixture (one of the biggest imports) is being imported from much narrower region compared to overall imports in Figure 4. This difference is another indication of validity for relative frequency method in analysing trade flows and patterns.

Breaking down import markets by goods in the $4^{\text {th }}$ group, it can be noted that closer markets tend to produce more goods and export them in more varying amounts than distant ones, which usually deal in big single time transactions or smaller periodical ones. Take variable nature of import from South and Southeast Asian countries in Figure 4 as an example, where imports of various goods were seasonal and not all year round, as for example, in imports from Latvia's neighbours such as Lithuania, Estonia or Poland.

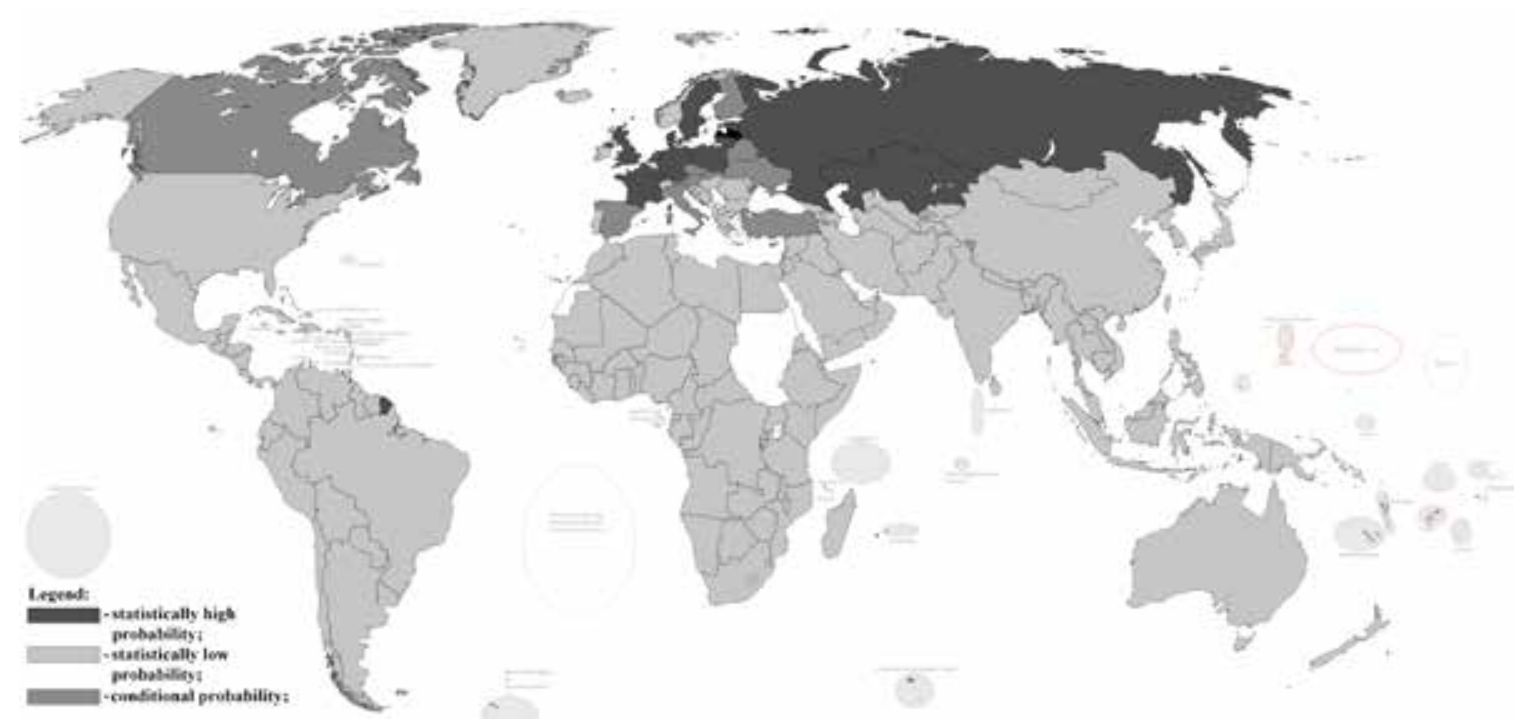

Figure 5. Import markets by import probability for mixture of wheat and rye in the observed period. 


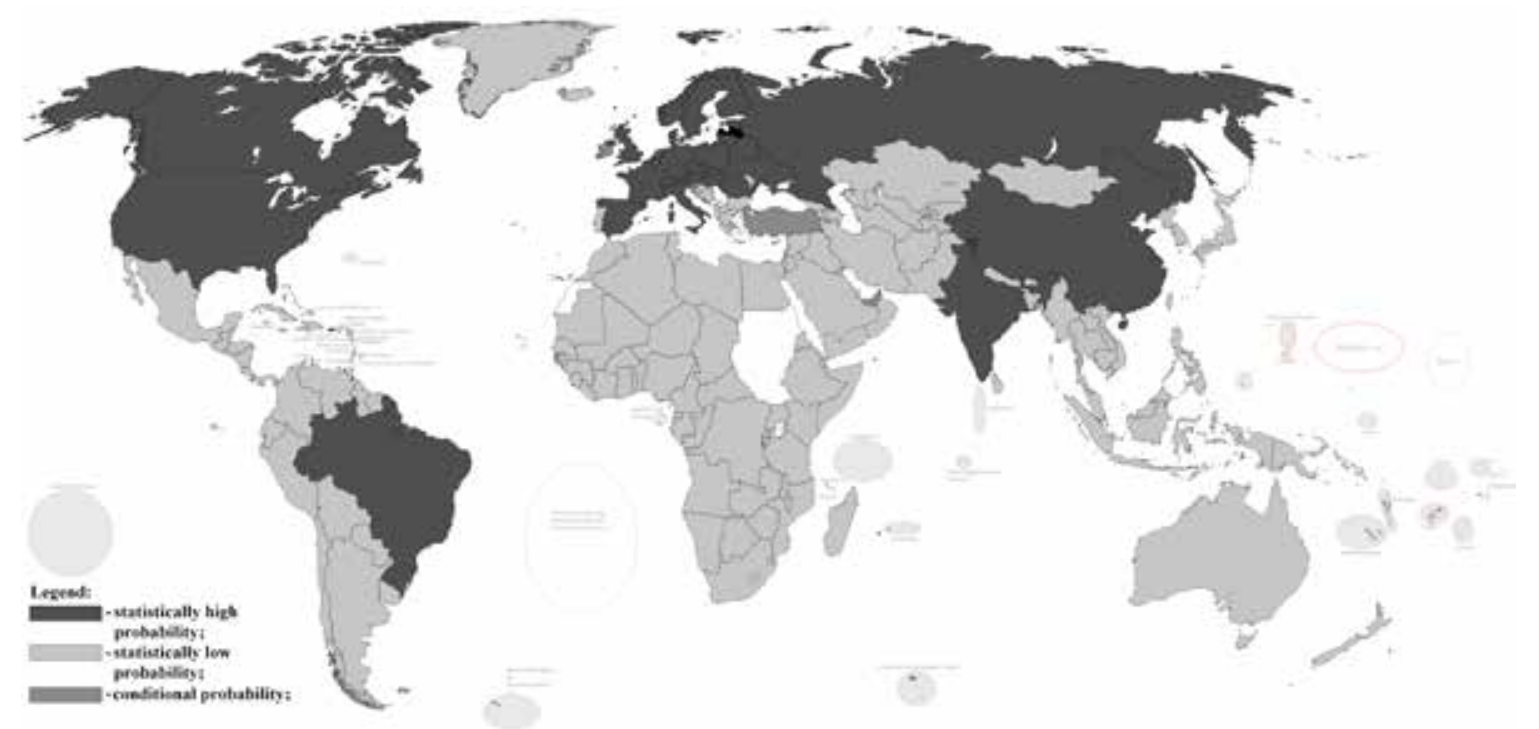

Figure 6. Import markets by import probability for wood and forestry produce in the observed period.

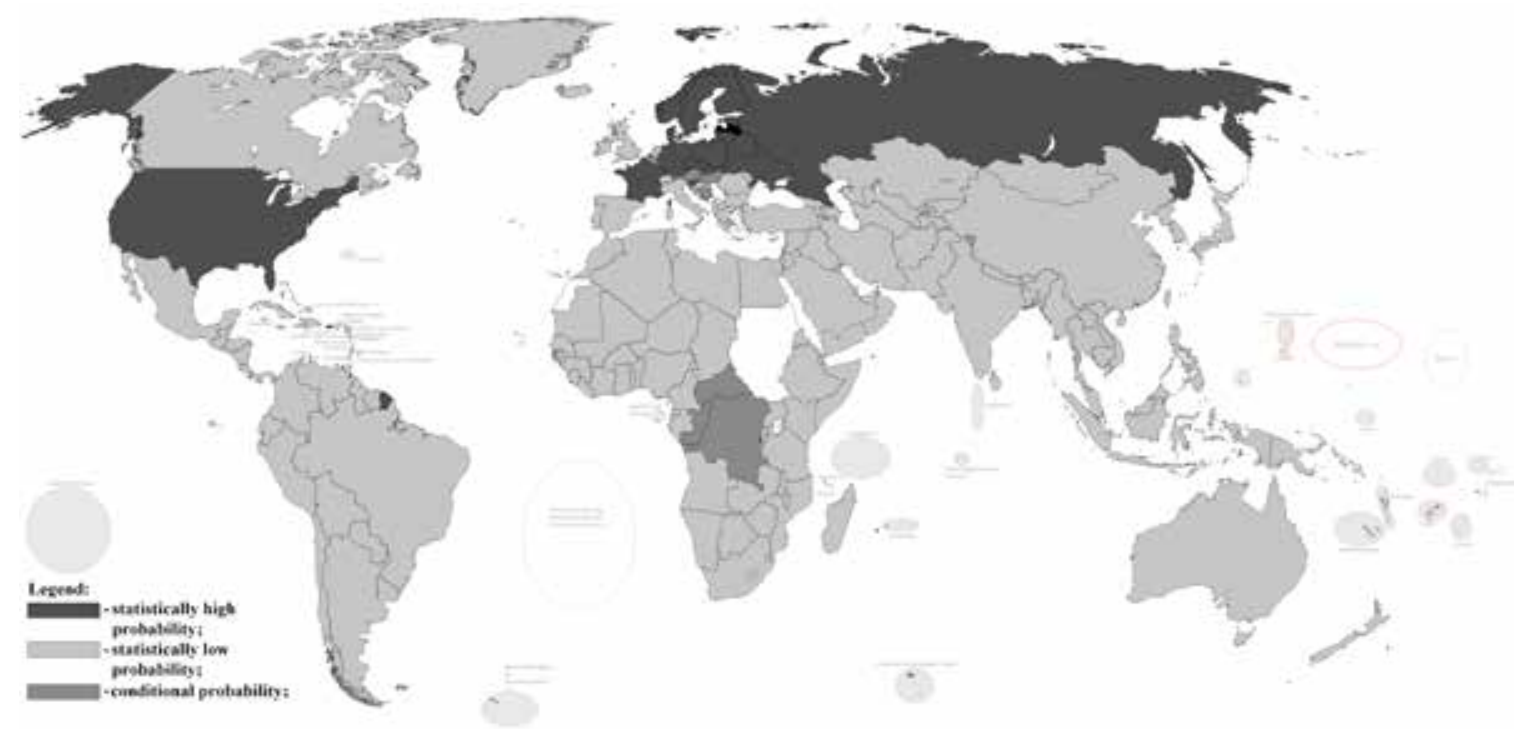

Figure 7. Import markets by import probability for log and wooden beam in the observed period.

Similar pattern in market-good dependency can be observed analysing the fifth group imports. Here we at first might observe significant variation of markets in Figure 6 and a sharp fall in it in Figure 7. Comparatively, to grain imports wood and its produce imports vary greatly due to nature of particular countries export and sectoral structure. Good examples, in this case, being Indian and Chinese imports in Figure 6 being that of highly processed construction materials, plywood, wooden element and containers, compared to varying nature of rare wood and log import from central African nations in Figure 7

Apart from those differences, there is a significant internal difference in trade pattern between far and close markets. In Europe, Latvia's close markets actively trade not only in logs and beams, but also in plywood, firewood, sawed construction materials and containers, while further markets specialise in decorative elements, sophisticated construction materials and high quality plywood and furniture. Among significant import markets Germany, Sweden, Poland and Check Republic can be noted as universal suppliers. Lithuania, Russia, Estonia and Finland can be described as importers of log, beam, sawed materials and generally of wood resources for local industry. Finally, distant markets such as the USA, France, Norway, while also trading in raw and lightly processed wood, are listed as major importers of wooden decorative elements, furniture and specific wooden produce. 


\section{Conclusions}

Findings from analysing the import flow have generally confirmed many of the previous paper (Berjoza \& Paiders, 2015) results and methodology used, proved to be useful in studying the import as much as it was useful in studying export. Overall, it can be concluded that relative frequency method is a good tool for observing long term relations between nations by analysing some continuous process or phenomenon that can be tracked and measured for a prolonged period of time.

By analysing Latvian import markets of agriculture, fisheries and forestry and observing the differences between the data acquired through two different empirical methods, it can be said that Latvian major importers are located in the Baltic Sea region (including Estonia, Lithuania, Finland, Sweden, Russia, Belarus, Poland, Germany, and Denmark) and adjoining nations (such as the Czech Republic, Norway, Slovakia, the Netherlands, Hungary and Austria). These findings are similar to those made previously, but in addition there are several new markets of significance: France, Spain, Italy and the
UK. Those new markets are significant in importing section of trade mostly due to high demand for high quality and luxurious goods. The USA, Canada, China and some other Southeast Asian countries can also be mentioned as a stable trading partners for Latvia, but their significance usually encompasses particular products group or even position. It is evident that import markets are more diverse and poses wider geography, compared to export - indicating a larger competition for markets globally and regionally than that observed in the study of export.

In addition to the results obtained, through this study a number of questions remain unanswered, particularly a better explanation for appearance of variable probability markets, the diversification and specialization of countries, periodicity of trade trends and patterns and also significance of Latvian trade for its main trading partner. All these questions pose a challenge and an opportunity for further work on the topic and a need for further studies in appliance of devised methodology and re-examination of data collected.

\section{References}

1. Berentsen, W.H. (2012). The Change in European Foreign Trade from 1960 to 2010: A Geography of Leading Merchandise Exporting Partners. Eurasian Geography \& Economics, 380 - 399.

2. Bergeijk, P.A.G. van (2009). Economic Diplomacy and the Geography of International Trade. Edward Elgar, Cheltenham, UK, 222.

3. Berjoza, A., \& Paiders, J. (2013). Geographical trends in export market of Latvian Fisheries production. Research for Rural Development - International Scientific Conference, 2, 208 - 214.

4. Berjoza, A., \& Paiders, J. (2015). Geographical tendencies of main produce exports of Latvia 2000 - 2013. Research for Rural Development 2015 - International Scientific Conference, 2, 139 - 145.

5. Bērtaite, L., \& Liepa, I. (2011). Analysis of tree felling, regeneration, import and export dynamics in Latvia. Research for Rural Development 2011 - International Scientific Conference, 2, 13 - 16.

6. Birzins, A. (2004). Bilateral diplomatic and economic relations between East Asia and the new EU members: The case of Latvia. Asia Europe Journal, 2, 221 - 235.

7. Chaney, T. (2014). The Network Structure of International Trade. The American Economic Review, 104(11), $3600-3634$.

8. Devaeva, E. (2006). Foreign Trade Flow Structure of the Russian Far East. Far Eastern Affairs, 34(3), $93-105$.

9. Eaton, J., Kortum, S., \& Kramarz, F. (2011). An Anatomy of International Trade: Evidence from French Firms. Econometrica, 79(5), $1453-1498$.

10. Fadejeva, L., \& Meḷihovs, A. (2009). Latvijas Tautsaimniecības nozaru kopējās faktoru produktivitātes un faktoru izmantošanas novērtējums. (General sectoral factor productivity and use of factor assessment of Latvian national economy) Retrieved April 21, 2011, from: http://80.233.167.45/public_files/images/ img_lb/izdevumi/latvian/citas/pet_2009-3_fadejeva-melihovs.pdf. (in Latvian).

11. Gingrich, S. (2011). Foreign trade and early industrialisation in the Habsburg Monarchy and the United Kingdom - Two extremes in comparison. Ecological Economics, 70(7), 1280 - 1288.

12. Haibo, L. (2004). Geoeconomics at Work. Beijing Review, 47(45), 3.

13. Herekenrath, M. (2007). Introduction: The Regional Dynamics of Global Transformations. International Journal of Comparative Sociology (Sage Publications, Ltd.), 48(2/3), 91 - 105.

14. Kantar, E., Deviren, B., \& Keskin, M. (2011). Hierarchical structure of Turkey's foreign trade. Physica A, $390(20), 3454-3476$.

15. Krastiņš, O., \& Ciemiņa, S. (2003). Statistika (Statistics). LR Centrālā statistikas pārvalde, Riga, Latvia, 267. (in Latvian). 
16. Novy, D. (2013). Gravity redux: measuring international trade costs with panel data. Economic inquiry, 51(1), $101-121$.

17. Villoria, N.B., Hertel, T.W. (2011). Geography Matters: International Trade Patterns and Indirect Land Use Effects of Biofuels. American Journal of Agricultural Economics, 93(4), 919 - 935. 